\title{
IMPLEMENTASI PEMBELAJARAN BIOLOGI BERBASIS SCIENTIFIC APPROACH DI SMA SWASTA UISU MEDAN TAHUN PEMBELAJARAN 2016/2017
}

\author{
Gepi Dianissa Dalimunthe, Amrizal, Sespin Renova, Nina Ratna Siregar \\ Program Studi Pendidikan Biologi, FMIPA, Universitas Negeri Medan, Medan \\ Jl. Willem Iskandar Psr. V Medan Estate, Medan, Indonesia, 20221 \\ E-mail: dianissagepi@yahoo.co.id
}

\begin{abstract}
ABSTRAK
Penelitian ini bertujuan untuk mengetahui: (1)kesesuaian RPP guru biologi dengan RPP berbasis kurikulum 2013; (2) kesesuaian pelaksanaan pembelajaran biologi berbasis pendekatan saintifik dengan RPP; (3) penerapan pengalaman belajar pendekatan saintifik pada pembelajaran biologi; (4) pengalaman belajar saintifik yang mengalami kendala pada pembelajaran biologi dan (5) solusi untuk kendala penerapan pengalaman belajar pendekatan saintifik pada pembelajaran biologi. Jenis penelitian ini adalah deskriptif kuantitatif. Populasi dari penelitian ini adalah guru biologi kelas X dan XI berjumlah 2 orang dan 111 siswa kelas X dan XI. Jumlah sampel pada penelitian ini adalah 2 orang guru biologi dan 98 siswa. Data penelitian diambil dari hasil observasi, angket, wawancara dan dokumentasi. Hasil penelitian menunjukan bahwa: (1) kesesuaian RPP guru biologi dengan RPP kurikulum 2013 tergolong baik (87,63\%) (2) kesesuaian pelaksanaan pembelajaran biologi dengan RPP tergolong cukup (74,51\%); (3) penerapan pengalaman belajar pendekatan saintifik secara keseluruhan kurang (48\%), pengalaman belajar yang dominan dilakukan adalah mengamati (81\%) dengan bentuk-bentuk pengalaman belajar berupa membaca, mendengar, menyimak dan melihat; (4) Pengalaman belajar pendekatan saintifik yang tidak dominan adalah mengasosiasi (7\%); (4) Solusi untuk mengatasi kendala memberikan latihan kepada siswa untuk memecahkan masalah dan memberikan argumen; menggunakan media pembelajaran; memberikan reward dan menyediakan referesnsi belajar untuk siswa; melakukan diskusi teman sejawat.
\end{abstract}

Kata Kunci: Pembelajaran, Pendekatan Saintifik, Pengalaman Belajar.

\section{ABSTRACT}

This research aimed to know: (1) suitability of plan of learning was made by biology teacher with plan of learning based of curicullum 2013; (2) suitability of the implementing of biology learning based on scientific approach with the implementation plan of learning; (3) implementing of learning experience of scientific approach in biology learning; (4) experience learning of scientific approach that is relatively difficult on the implementing of scientific approach in biology learning; (5) Solution in solving obstacles of implementing learning experience of scientific approach in biology learning. Type of this research was quantitative descriptive research. The population of this research was the biology teacher of class $X$ and XI which amounted to 2 people and 111 students of class $X$ and XI. Total sample were 2 teachers and 98 students. The research data was taken by observation, questionnaire, interview and documentation. The results showed that: (1) the suitability of plan of learning was made by biology teacher with plan of learning of curicullum 2013 belonging to the category was good $(87,63 \%)$; (2) the suitability of the implementing of biology learning biology learning based on scientific approach with the implementation plan of learning belonging to the category was quite (74.51\%); (3) the implementing of learning experience of scientific approach in biology learning by student overall was less (48\%) With the dominant learning experience was observed (81\%) with forms of learning experience in the form of reading, listening, listening and seeing; (4) The learning experience of scientific approach not dominant was associate belonging to the category was less (7\%); (5) Solution to overcome obstacles are provides practice to students to solve problems and states the argument, use media in learning gives reward and provide the learning references to students; doing peer discussions

Keywords: learning, learning experience, scientific approach. 
JURNAL PELITA PENDIDIKAN VOL. 5 NO. 3

Dalimunthe, GD., Amrizal, Renova , S., Siregar, RN.

Halaman : $306-312$

\section{PENDAHULUAN}

Sejak diberlakukannya Kurikulum 2013, sebanyak 260 sekolah (70 sekolah diantaranya SMA) di Sumatera Utara telah menerapkannya dalam penyelenggaraan pendidikan di SMA (marhadikanews.com, 2013; Feriansyah, 2013). Setelah diterbitkan Surat Edaran Menteri Pendidikan dan Kebudayaan No 179342/MPK/KR/2014 Tanggal 5 Desember 2014 tentang Pelaksanaan Kurikulum 2013, dan Permendikbud No. 160 Tahun 2014 Tentang Pemberlakuan Kurikulum 2006 dan Kurikulum 2013, di mana sekolah yang tetap menerapkan Kurikulum 2013 hanya sekolah-sekolah yang telah menerapkan kurikulum 2013 selama tiga semester, yaitu sejak Tahun Pelajaran 2013/2014 dengan demikian SMA Swasta UISU tetap menerapkan kurikulum baru ini.

Memang, kalau ditelaah lebih jauh perubahan yang terjadi sebagai akibat pengembangan kurikulum 2006 menjadi kurikulum 2013 lebih cenderung pada pengaturan alokasi waktu, perubahan standar kompetensi menjadi kompetensi inti, dan sistem penilaian. Dalam implementasinya justru tidak terlalu jauh mengalami perubahan. Misalnya, Kurikulum 2013 menerapkan pendekatan saintifik (scientific approach), pada kurikulum 2006 sebelumnya menerapkan pendekatan inquiry saintifik. Langkah 5M pada pendekatan saintifik merupakan pengembangan dari 3 langkah pokok kegiatan inti pembelajaran, yakni: (1) eksplorasi (mengamati dan menanya); (2) elaborasi (menguji, dan menalar), dan (3) konfirmasi (mengkomunikasikan). Sehingga, seharusnya tidak ada kendala khusus dalam penerapan kurikulum 2013 khususnya di SMA Swasta UISU. Sanjaya (2008) menuliskan, bahwa penerapan pendekatan pada pembelajaran sangat bergantung pada guru. Jika guru dapat menerjemahkan kurikulum menjadi langkah pembelajaran yang operasional di kelas, maka sesungguhnya seberapa besarpun perubahan yang terjadi pada kurikulum, guru sebagai pendidik profesional sudah seharusnya dapat menyesuaikannya dalam pembelajaran.

Pendekatan saintifik yang merupakan ciri khas dari kurikulum 2013 adalah pendekatan pembelajaran yang dirancang sedemikian rupa agar peserta didik secara aktif mengkonstruksi konsep, hukum, atau prinsip melalui tahapan-tahapan mengamati (untuk mengidetifikasi atau merumuskan masalah), merumuskan masalah, mengajukan atau merumuskan hipotesis, mengumpulkan data, menganalisis data, menarik kesimpulan dan mengkomunikasikan konsep, hukum atau prinsip yang ditemukan. Pendekatan
pISSN : 2338 - 3003

elSSN : 2502 - 3217

saintifik dimaksudkan untuk memberikan pemahaman kepada peserta didik, bahwa informasi itu dapat diperoleh darimana saja, tidak hanya bergantung pada guru. Sehingga pada pelaksanaannya guru dituntut untuk membimbing siswa melaksanakan pengalaman belajar saintifik yang mendorong dan melatih siswa untuk belajar secara mandiri.

Berdasarkan studi pendahuluan yang dilakukan, sejak diimplementasikan hingga sekarang (2017), pelaksanaan kurikulum 2013 di SMA Swasta UISU belum dievaluasi khususnya pada penerapan lima pengalaman belajar pendekatan saintifik pada pembelajaran biologi. Di samping itu, hasil wawancara dengan guru, didapati bahwa guru biologi sudah mulai menerapkan pembelajaran dengan pendekatan saintifik sejak awal di terapkannya Kurikulum 2013 pada SMA Swasta UISU Medan yaitu sejak Tahun Pembelajaran 2013/2014 walaupun penggunaan pendekatan saintifik tidak selalu digunakan guru untuk setiap materi pembelajaran. Penerapan pembelajaran dengan pendekatan saintifik terkadang masih tidak sesuai dengan apa yang sudah direncanakan oleh guru karena guru masih mengalami kendala dalam penerapannya sehingga tidak semua pengalaman belajar dari lima pengalaman belajar pendekatan saintifik dapat dilaksanakan pada kegiatan pembelajaran.

Hasil penelitian Aeni, dkk (2016) ditemukan, bahwa guru masih mengalami kesulitan dalam menerapkan pendekatan berbasis saintifik (mengamati, menanya, mencoba/mengumpulkan informasi, mengasosiasi dan mengkomunikasikan). Seillariski (2015), melaporkan kendala yang dihadapi guru adalah kurangnya pemahaman dan persiapan guru terkait dengan pendekatan saintifik sehingga proses pembelajaran dengan pendekatan saintifik belum berjalan maksimal.

Mengacu pada uraian latar belakang di muka, untuk kepentingan evaluasi pelaksanaan kurikulum 2013 di SMA Swasta UISU khususnya pada penerapan pembelajaran biologi berbasis pendekatan saintifik, perlu dilakukan penelitian tentang penerapan pembelajaran dengan pendekatan saintifik pada pembelajaran biologi. penelitian akan dilakukan terhadap pelaksanaan pembelajaran biologi di kelas $X$ dan XI dengan menggunakan instrumen yang disusun oleh peneliti dan telah divalidasi oleh ahli. Untuk mendapatkan informasi yang lebih luas penelitian dilakukan dengan observasi dan dilanjutkan dengan pembagian angket pada siswa serta wawancara mendalam (indept interview) dengan guru (praktisi). 


\section{METODE PENELITIAN}

Penelitian dilakukan di SMA Swasta UISU Medan di Jalan H. Bahrum Jamil, SH Gg. UISU No.2 Teladan Barat. Penelitian dilakukan pada bulan Februari - Juni 2017. Populasi pada penelitian ini adalah 2 orang guru biologi dan 111 siswa. Teknik sampel dilakukan dengan teknik purposive sampling sebanyak 2 orang guru biologi 98 siswa sebagai sampel penelitian. Jenis penelitian ini adalah deskriptif kuantitatif . Instrumen penlitian ini yaitu lembar penilaian RPP guru biologi, lembar observasi aktivitas guru dan siswa dalam pelaksanaan pembelajaran biologi berbasis saintific approach, angket siswa untuk mengetahui aktivitas guru dalam pembelajaran biologi berbasis scientific approach sehingga diketahui pengalaman belajar saintifik yang dominan dilakukan siswa dan yang tidak dominan dilakukan, lembar wawancara guru untuk mengetahui kendala guru dalam menerapkan pendekatan saintifik, dan instrumen dokumentasi untuk mengetahui ada atau tidak literatur sebagai sumber solusi untuk mengatasi kendala dalam pembelajaran biologi dengan pendekatan saintifik. Teknik analisis data yang digunakan adalah analsis data statistik deskriptif. Seluruh data dianalisis dengan statistik sederhana dengan menghitung skor dibagi dengan skor ideal, kemudian di interpretasikan ke dalam kategori amat baik $(90<A \leq 100)$, baik $(80<B \leq$ 90), cukup ( $70<C \leq 80)$. dan kurang ( $\leq 70)$ Penyajian data dilakukan dengan tabel, perhitungan rata-rata dan perhitungan persentase dan mendeskripsikan keterangan yang didapat sebagai data.

\section{HASIL DAN PEMBAHASAN}

Kesesuaian Rencana Pelaksanaan Pembelajaran (RPP) yang disusun Guru Biologi dengan RPP Berbasis Kurikulum 2013

Berdasarkan hasil penilaian diketahui bahwa kesesuaian RPP yang disusun oleh guru biologi di SMA Swasta UISU Medan dengan RPP berbasis kurikulum 2013 sudah termasuk pada kategori baik dengan nilai presentase $87,63 \%$. Namun pada beberapa komponen RPP mendapat kategori cukup dan kurang. Aspek pengamatan yang mendapat kategori kurang dengan nilai presentase sebesar $66,67 \%$, adalah aspek tujuan pembelajaran, Aspek penilaian yang termasuk dalam kategori cukup adalah perumusan indikator dengan presentase nilai sebesar $77,78 \%$ dan rancangan penilaian pembelajaran dengan presentase nilai sebesar $75 \%$. Aspek penililaian yang termasuk dalam kategori baik yaitu skenario pembelajaran dengan presentase nilai sebesar $86,67 \%$. Aspek penilaian yang termasuk dalam kategori amat baik yaitu identitas pembelajaran, pemilihan sumber pembelajaran, pemilihan media pembelajaran dengan presentasi nilai maing-masing $100 \%$ dan pemilihan materi ajar dengan presentase nilai sebesar $91,66 \%$.

\section{Kesesuaian Pelaksanaan Pembelajaran dengan RPP}

Setelah melakukan observasi dan analisis data didapatkan rata-rata kesesuaian pelaksanaaan pembelajaran biologi dengan RPP memperoleh nilai 73\% secara keseluruhan dengan intepretasi cukup. Pada kegiatan pendahuluan dan inti rata-rata pelaksaanaan cukup sesuai dengan RPP dengan perolehan nilai masing-masing $79 \%$ dan $72 \%$ namun pada kegiatan penutup diperoleh pelaksanaan kurang sesuai dengan RPP dengan perolehan nilai $64 \%$.

\section{Aktivitas Siswa Dalam Pelaksanaan Pembelajaran Biologi Berbasis Pendekatan Saintifik}

Berdasarkan hasil observasi didapatkan bahwa pengalaman belajar saintifik yang paling dominan pada pembelajaran biologi di SMA Swasta UISU Medan adalah mengamati dengan bentuk-bentuk pengalaman belajar berupa membaca buku atau sumber belajar lain, mendengarkan penjelasan guru, mendengarkan presentasi yang dilakukan oleh siswa lain, mengamati gambar (gambar hewan, gambar alat-alat reproduksi, gambar siklus menstruasi dan gambar alur spermatogenesis dan oogenesis), mengamati video pembelajaran (video fertilisasi), mengamati morfologi dan anatomi ikan mas secara langsung. Pengalaman belajar yang paling tidak dominan adalah mengasosiasi. Hal ini sejalan dengan hasil wawancara guru yang mengatakan bahwa pengalaman megasosiasi merupakan pengalaman belajar yang paling jarang dilakukan dikarenanakan beberapa kendala. 


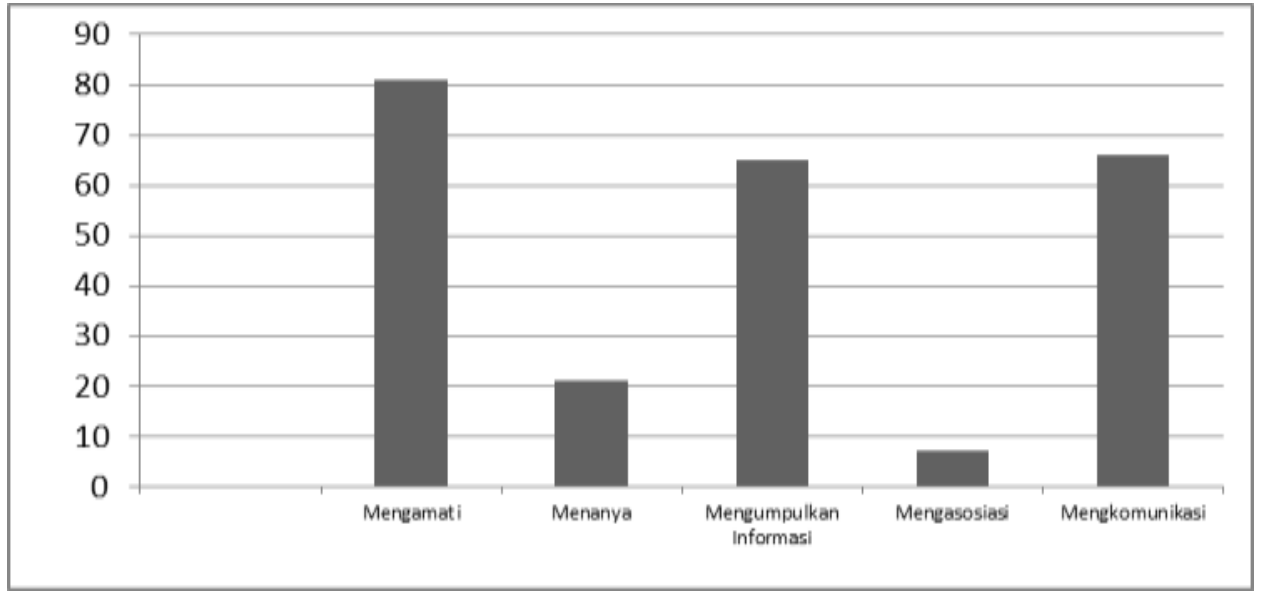

Gambar 1. Rata-Rata Nilai Pengalaman Belajar Pendekatan Saintifik Siswa

\section{Aktivitas Guru Dalam Pelaksanaan Pembelajaran Biologi Berbasis Pendekatan Saintifik}

Pada kegiatan pendahuluan diperoleh nilai ratarata $78,2 \%$ dengan interpretasi cukup. Pada kegiatan inti diperoleh interpretasi cukup pada aktivitas penerapan pendekatan saintifik, sumber belajar/media dalam pembelajaran dan pelaksanaan penilaian autentik dengan nilai rata-rata di atas $70 \%$. Pada kegiatan penutup diperoleh nilai rata-rata sebesar $46,7 \%$ dengan interpretasi kurang pada aktivitas pelaksanaan penutup pembelajaran.

\section{PEMBAHASAN}

Berdasarkan wawancara yang dilakukan pada guru biologi kelas $\mathrm{X}$ dan $\mathrm{XI}$, pada umumnya mereka telah melakukan persiapan sebelum melakukan pembelajaran baik itu dari segi RPP, silabus dan media pembelajaran. Guru biologi di SMA Swasta UISU Medan juga sudah terbiasa menggunakan pendekatan saintifik walaupun dalam pelaksanaannya terdapat beberapa pengalaman belajar yang tidak dapat dilakukan sesuai dengan yang tercantum pada RPP. Tidak hanya itu, beberapa kegiatan yang tercantum di RPP yang mempengaruhi kualitas pembelajaran juga masih ada yang tidak terlaksanakan. Penggunaan media pembelajaran yang pada RPP seharusnya dilakukan terkadang tidak dilakukan oleh guru. Menurut Sanjaya (2012), melalui proses perencanaan yang matang, guru dapat memprediksi seberapa besar keberhasilan yang akan dapat dicapai. Pembelajaran bukan hanya sekedar menyampaikan materi pembelajaran, tetapi suatu proses pembentukan perilaku siswa. Oleh karena itu, proses pembelajaran merupakan suatu yang kompleks dan harus diperhitungkan segala kemungkinan. Segala kemungkinan tersebut perlu perencanaan yang matang dari setiap guru.

Adanya komponen RPP yang memiliki nilai kurang dan cukup dikarenakan terdapat beberapa hal yang seharusnya terdapat pada RPP yang akan digunakan guru berdasarkan tuntutan kurikulum 2013, namun tidak tampak pada RPP tersebut. Tujuan pembelajaran yang merupakan komponen RPP yang mendapatkan presentase paling rendah dikarenakan tujuan yang dijabarkan oleh guru tidak mengandung audience, behaviour, condition, dan degree, selain itu tujuan pembelajaran yang dibuat sebagian tidak memuat semua tujuan pembelajaran yang seharusnya dikembangkan dari KD . Menurut Kosasih (2014), tujuan pembelajaran merupakan arah atau sasaran dari suatu kegiatan pembelajaran, oleh karena itu rumusannya harus jelas dan lengkap (mengandung unsur audience, behaviour, condition, dan degree) serta dirumuskan dari KD dalam kurikulum. Rendahnya perolehan nilai kesesuaian pada aspek rancangan penilaian pembelajaran pada penelitian ini sesuai dengan hasil penelitian yang pernah dilakukan oleh Asarina (2014) ditemukan guru kesulitan membuat dan mengebangkan instrumen penilaian pembelajaran.

Presentase kesesuaian pelaksanaan pembelajaran dengan RPP guru yang memperoleh nilai cukup juga dapat disebabkan karena perencanaan yang kurang maksimal. Perencanaan yang kurang maksimal dapat terlihat pada penilaian RPP yang akan digunakan oleh guru. masih terdapat aspek yang kurang sesuai dengan RPP berbasis kurikulum 2013 yaitu pada perumusan tujuan pembelajaran. Seharusnya tujuan pembelajaran harus 
disusun dengan baik dan benar karena tujuan pembelajeran merupakan arah atau sasaran dari suatu kegiatan pembelajaran. Nilai kesesuaian yang hanya memperoleh kategori cukup sesuai terdapat pada aspek perumusan indikator pembelajaran dan rancangan penilain pembelajaran. Rancangan penilaian pembelajaran yang tidak maksimal menyebabkan kegiatan penilaian tidak terlaksana dengan baik pada saat pembelajaran. Menurut Hariyanto (2009), perencanaan yang baik sangat membantu pelaksanaan pembelajaran. Dalam pembelajaran akan dibutuhkan komitmen yang kuat untuk menerapkan perencanaan yang telah dirancang dengan baik.

Dari lima pengalaman belajar saintifik, pengalaman belajar yang paling dominan dilakukan oleh siswa adalah mengamati dengan perolehan presentase siswa yang melakukan sebanyak $81 \%$ dengan interpretasi baik. bentuk-bentuk kegiatan yang dilakukan siswa dalam mengamati yaitu, membaca buku atau sumber belajar lain, mendengarkan penjelasan guru, mendengarkan presentasi yang dilakukan oleh siswa lain, mengamati gambar (gambar hewan, gambar alat-alat reproduksi, gambar siklus menstruasi dan gambar alur spermatogenesis dan oogenesis), mengamati video pembelajaran (video fertilisasi), mengamati morfologi dan anatomi ikan mas secara langsung. Bentukbentuk pengalaman belajar yang difasilitasi oleh guru dan dilakukan oleh siswa ini merupakan bentuk pengalaman belajar yang memang seharusnya ada pada proses melakukan pengalaman belajar mengamati, sesuai dengan pernyataan Kosasih (2014), langkah pertama dalam proses pembelajaran saintifik adalah mengamati. Prosesnya dapat dilalui melalui membaca sumber-sumber tertulis, mendengar informasi lisan, melihat gambar dan sejenisnya, menontong tayangan, dan menyaksikan fenomena alam, sosial, budaya.Dapat dikatakan bahwa selama melakukan pengalaman belajar saintifik mengamati, bentuk-bentuk pengalaman belajar yang dilakukan siswa adalah membaca, mendengar, menyimak dan melihat. Pengalaman belajar yang paling tidak dominan (mengalami kendala) dilakukan selama proses pengamatan pembelajaran biologi di SMA Swasta UISU Medan adalah kegiatan mengasosiasi. Hasil ini sesuai dengan hasil temuan Astuti (2016) yang mengatakan bahwa kegiatan mengasosiasi masih kurang maksimal dilakukan pada proses pembelajaran.

Berdasarkan hasil wawancara dengan guru-guru biologi didapatkan bahwa mengasosiasi merupakan pengalaman belajar pendekatan saintifik yang paling jarang dilaksanakan dikarenakan keterbatasan waktu yang tersedia dan beberapa hal yang meyebabkan penggunaan waktu kurang efektif, seperti tidak semua siswa memiliki buku pegangan dan masih banyak murid yang malu-malu serta tidak aktif untuk mengeluarkan pendapat ketika diberi pertanyaan mengenai hal-hal yang berkaitan dengan penerapan materi yang telah dipelajari. beberapa kendala pada pelaksanaan pembelajaran biologi berbasis pendekatan saintifik khususnya pada kegiatan mengasosiasi yaitu, (1) Siswa yang tidak aktif dan malu-malu; (2) Penggunaan waktu yang kurang efektif; (3) kurangnya persiapan oleh guru.

Solusi untuk mengatasi siswa yang tidak aktif dapat diatasi dengan menggunakan media pembelajaran, reward, dan pemberian latihan. Purwanti (2010), menyatakan bahwa penggunanaan media konkret dapat meningkatkan aktivitas belajar siswa. Selain meningkatkan aktivitas siswa, motivasi belajar siswa juga dapat ditingkatkan melalui media pembelajaran sesuai dengan hasil penelitian Kartikasari (2016), didapatkan bahwa terdapat pengaruh yang signifikan penggunaan media pembelajaran terhadap motivasi belajar siswa. Menurut Suyanto (2013) penggunaan media dapat dikaitkan dengan konsep, pemahaman konsep, latihan dan penguatan, pelayanan terhadap perbedaan kemampuan individual, pemecahan masalah pada umumnya, rangsangan untuk berfikir, rangsangan untuk berdiskusi, serta rangsangan untuk berpartisipasi aktif. Selain itu keaktifan belajar siswa dapat ditingkatkan dengan melakukan pemberian reward kepada siswa, sesuai dengan hasil penelitian Jannah (2013) didapatkan bahwa pemberian reward berpengaruh positif terhadap keaktifan belajar siswa dalam mengikuti pelajaran. Menurut Sani (2014), upaya untuk melatih siswa dalam melakukan penalaran dapat dilakukan dengan meminta siswa untuk menganalisis data yang telah diperoleh sehingga mereka dapat menemukan hubungan antar variabel, atau dapat menjelaskan tentang data berdasarkan teori yang ada, menguji hipotesis yang telah diajukan, dan membuat kesimpulan

Kendala dalam mengatasi penggunaan waktu yang kurang efektif yang diakibatkan kurangnya sumber belajar dapat diatasi dengan solusi pemberian referensi oleh guru sehingga siswa tidak berpatok pada buku cetak atau internet saja. Menurut Kosasih (2016), agar siswa dapat melakoni kegiatan mengasosiasi guru harus memfasilitasi siswa dengan menyediakan sejumlah referensi dan latihan yang bisa 
memperkaya dan memperdalam pemahaman mereka terkait KD yang sedang dikembangkan.

Kurangnya persiapan guru tampak dari tidak selalu tersedianya yang seharusnya ada pada saat mengasosiasi, selain itu media pembelajaran juga tidak selalu ada seperti yang tercantum pada skenario RPP. Untuk mengatasi kesulitan guru dalam mempersiapkan bahan ajar, solusi yang dapat dilakukan adalah dengan bekerjasama dengan guru lain/teman sejawat untuk mempersiapkan bahan ajar/perangkat pembelajaran, sesuai dengan hal yang dikemukakan Kinasih (2017), bahwa upaya guru untuk mengatasi permasalahan dalam menyusun perangkat pembelajaran adalah dengan diskusi teman sejawat menggunakan media pembelajaran yang sederhana dan media sudah tersedia di sekolah.

\section{KESIMPULAN}

Kesesuaian RPP yang disusun guru biologi di SMA Swasta UISU Medan dengan RPP berbasis kurikulum 2013 tergolong dalam kategori baik dengan presentase $87,63 \%$. Kesesuaian pelaksanaan pembelajaran biologi dengan RPP di SMA Swasta UISU Medan Tahun Pembelajaran 2016/2017 tergolong dalam kategori cukup sesuai dengan presentase $79 \%$ pada kegiatan pendahuluan, $75,07 \%$ pada kegiatan inti dengan kategori cukup, 64\% pada kegiatan penutup dengan kategori kurang, dan secara keseluruhan sebesar $74,51 \%$ dengan kategori cukup. Pengalaman belajar pendekatan saintifik yang dominan dilakukan siswa kelas $X$ dan XI di SMA Swasta UISU Medan selama pembelajaran biologi adalah mengamati dengan presentase siswa yang melakukan sebanyak $81 \%$ dengan kategori baik dengan bentuk-bentuk pengalaman belajar berupa membaca, mendengar, menyimak dan melihat. Pengalaman belajar pendekatan saintifik yang tidak dominan (kendala dalam pelaksanaan pendekatan saintifik) dilakukan siswa kelas X dan XI di SMA Swasta UISU Medan selama pembelajaran biologi adalah mengasosiasi dengan presentase siswa yang melakukan sebanyak 7\% dengan kategori kurang. Solusi untuk mengatasi kendala dalam mengimpelemntasikan pengalaman belajar mengasosiasi pada pelaksanaan pembelajaran biologi dengan pendekatan saintifik di SMA Swasta UISU Medan adalah guru sebaiknya memberikan latihan kepada siswa untuk memecahkan masalah dan memberikan argumen; menggunakan media pembelajran; memberikan reward dan menyediakan referesnsi belajar untuk siswa; melakukan diskusi teman sejawat.

\section{DAFTAR PUTAKA}

Aeni, U., Chandra, E., Muspiroh,N, (2016), Identifikasi Kesulitan Guru Biologi Dalam Melaksanakan Pembelajaran Kurikulum 2013 Di Sma Negeri 1 Susukancirebon, Jurnal Sains dan Pendidikan Sains 5 (2): 165-174

Asarina, R., (2014), Studi Eksplorasi Kendala-Kendala Guru Dalam Pembelajaran IPS Di SMP Wilayah Kecamatan Moyudan, Jurusan Pendidikan Ilmu Pengetahuan Sosial, Universitas Negeri Yogyakarta, Yogyakarta

Astuti, L, D., (2016) Analisis Pelaksanaan Pembelajaran Matematika Materi Transformasi dengan pendekatan Saintifik Kurikulum 2013 di Kelas VII SMP Negeri 2 Wedi Tahun Ajaran 2015/2016, Skripsi, Jurusan Pendidikan Matematika dan IImu Pengetahuan Alam, Universitas Sanata Dharma, Yogyakarta

Feriansyah, (2013), 260 Sekolah di Sumut Terapkan Kurikulum 2013, http://medan.tribunnews.com/2013/07/22/2 60-sekolah-di-sumut-terapkan-kurikulum2013

Hariyanto, D., (2009), Kinerja Guru Kejuruan yang telah Bersertifikat Pendidik di SMKN SeKota Malang, Universitas Negeri Malang : Malang

Jannah, A., (2013), Pengaruh Pemberian Reward Guru Terhadap Keaktifan Belajar Siswa Kelas XI Dalam Mengikuti Pelajaran Al Qur'an Hadits MAN Tengaran Kab. Semarang Tahun Pelajaran 2013, Skripsi, Jurusan Tarbiyah, Sekolah Tinggi Agama Islam Negeri Salatiga, Salatiga

Kartikasari, Galuh., (2016), Pengaruh Media Pembelajaran Berbasis Multimedia Terhadap Motivasi dan Hasil Belajar Materi Sistem Pencernaan Manusia Studi Eksperimen Pada Siswa Kelas V Mi Miftahul Huda Pandantoyo, Dinamika Penelitian, 16 (1): 59-77

Kinasih, A,R., (2017), Problematika Guru Dalam Penyusunan Perangkat Pembelajaran Di SD Muhammadiyah 14 Surakarta, Program Studi 
Pendidikan Guru Sekolah Dasar, Universitas Muhammadiyah Surakarta, Surakarta

Kosasih,E., (2014), Strategi Belajar dan Pembelajaran Implementasi Kurikulum 2013, Yrama Widya, Bandung

Mahardikanews.

(2013), http://mahardikanews.com/view/Pendidikan /137/Baru-260-Sekolah-di-Sumut-TerapkanKurikulum-2013.htm

Purwanti, L., (2010), Peningkatan Aktivitas Pembelajaran IPA Dengan Media Benda Konkret Pada Siswa Kelas li SDN 01 Kaling Tasikmadu Karanganyar Tahun 2009/ 2010, Skripsi, FKIP, Universitas Sebelas Maret, Surakarta.

Sani, R.A., (2014). Pembelajaran Saintifik untuk Implementasi Kurikulum 2013. Jakarta: PT Bumi Aksara

Sanjaya, W., (2012), Strategi Pembelajaran Berorientasi Standar Proses Pendidikan, Kencana Prenada Media Group, Jakarta

Seillariski, I., (2015), Implementasi Pendekatan Saintifik Dalam Pembelajaran Sejarah di SMA Negeri 1 Rembang., Skripsi, FIS, Universitas Negeri Semarang, Semarang

Supardi., (2015), Penilaian Autentik Pembelajaran Afektif, Kognitif, dan Psikomotor, Raja Grafindo Persada, Jakarta 